Vol. 17 (2008): 73-87.

\title{
Residual effect of clover-rich leys on soil nitrogen and successive grain crops
}

\author{
Arja Nykänen \\ MTT Agrifood Research Finland, Plant Production, Lönnrotinkatu 3, FI-50100 Mikkeli, Finland, \\ e-mail:arja.nykanen@mtt.fi \\ Arthur Granstedt \\ Biodynamic Research Institute, Skilleby farm, SE-15391 Järna, Sweden \\ Lauri Jauhiainen \\ MTT Agrifood Research Finland, Data and Information services, FI-31600 Jokioinen, Finland \\ Antti Laine \\ MTT Agrifood Research Finland, Plant Production, Toivonlinnantie 518, FI-23120 Piikkiö, Finland
}

Legume-based leys form the basis for crop rotations in organic farming as they fix nitrogen $(\mathrm{N})$ from the atmosphere for the succeeding crops. The age, yield, C:N, biological $\mathrm{N}$ fixation (BNF) and total $\mathrm{N}$ of red clover-grass leys were studied for their influence on yields, $\mathrm{N}$ uptake and $\mathrm{N}$ use efficiency (NUE) of the two sequential cereal crops planted after the leys. Mineral $\mathrm{N}$ in deeper soil $(30-90 \mathrm{~cm})$ was measured to determine N leaching risk. Altogether, four field experiments were carried out in 1994-1998 at two sites. The age of the ley had no significant effect on the yields and $\mathrm{N}$ uptake of the two subsequent cereals. Surprisingly, the residual effect of the leys was negligible, at $0-20 \mathrm{~kg} \mathrm{~N} \mathrm{ha}^{-1} \mathrm{yr}^{-1}$. On the other hand, the yield and C:N of previous red clover-grass leys, as well as BNF-N and total-N incorporated into the soil influenced subsequent cereals. NUEs of cereals after ley incorporation were rather high, varying from $30 \%$ to $80 \%$. This might indicate that other factors, such as competition from weeds, prevented maximal growth of cereals. The mineral $\mathrm{N}$ content deeper in the soil was mostly below $10 \mathrm{~kg} \mathrm{ha}^{-1}$ in the sandy soil of Juva, but was $5-25 \mathrm{~kg} \mathrm{ha}^{-1}$ in clayey soil of Mietoinen.

Key-words: age of the ley, Biological nitrogen fixation, $\mathrm{C}: \mathrm{N}$, crop rotation, mineral nitrogen, nitrogen leaching, nitrogen use efficiency, red clover ley, Trifolium pratense 
Nykänen, A. et al. Residual effect of clover-rich leys

\section{Introduction}

Crop rotations, including legume-based leys and arable crops, are the basis of organic farming, where biological nitrogen fixation (BNF) of legumes provides soil nitrogen that is utilised by the subsequent crops. The whole biomass of the ley acts as fertiliser for the subsequent crops, if the ley is used as green manure. In the case of fodder production, only the crop residues, i.e. stubble and roots of the ley biomass, can function as fertiliser for the subsequent crop. This biomass can be as much as $40 \%$ of the whole biomass of leys (Hansson 1987, Granstedt 1992).

Ploughing of the leys is followed by substantial mineralisation of both crop residues and soil organic matter. This mineralised nitrogen $(\mathrm{N})$ can be used by subsequent crops, lost in some form to the surrounding environment or retained in the soil organic matter, where it contributes to humus formation (Allison 1973, Jansson and Persson 1982, Granstedt 1992). In order to maximise $N$ use by crops and minimise $\mathrm{N}$ losses to the environment, it is important to quantify the effect of leys on subsequent crop as well as qualify the characteristics of leys that influence their residual effects.

Several studies have already defined some of the factors that may influence residual $\mathrm{N}$ effect of leys. Høgh-Jensen and Schjoerring (1997) found that the clover content, $\mathrm{N}_{2}$-fixation and yield of preceding ley have an effect on the subsequent wheat yield. Känkänen et al. (1999) also found the $\mathrm{N}$-content of green manure crops to have an influence on the succeeding cereal growth. According to Haynes (1986), a N content above 2.0-2.5\%, corresponding to a $\mathrm{C}: \mathrm{N}$ of $20-25$, in incorporated biomass results in net $\mathrm{N}$ mineralisation in the soil. $\mathrm{N}$ mineralisation is affected by plant composition including content of lignin, carbohydrates and polyphenols in the incorporated biomass (Haynes 1986, Honeycutt et al. 1993). In addition, climatic conditions can have a substantial effect on the $\mathrm{N}$ mineralisation of crop residues and soil organic $\mathrm{N}$. These properties can be combined in different ways in leys of different ages, as was shown in studies of Granstedt and Baeckström (1998), where 2-year- old red clover leys as pre-crops increased wheat yields more than 1- or 3-year-old leys. Although red clover (Trifolium pratense) is one of the most common perennial legume in leys in temperate regions, its residual effect in cutting systems has rarely been studied, at least not with no supplementation of mineral fertilisers or manure.

The technique and timing of incorporation of $\mathrm{N}$-rich biomass can have a major effect on $\mathrm{N}$ leaching. Several studies show that early ploughing in autumn increases $\mathrm{N}$ leaching compared to ploughing in late autumn or in spring (Francis et al. 1992, Djurhuus and Olsen 1997, Känkänen et al. 1998). Catch crops, such as ryegrass, for example, can reduce $\mathrm{N}$ leaching (Francis 1995). Winter rye can also be considered as a catch crop, but in Denmark, for example, winter rye as the subsequent crop to grass-clover ley was not able to take up all of the mineralised $\mathrm{N}$ during the winter period in sandy soils (Djurhuus and Olsen 1997). The decrease in the yield and BNF (i.e. N content) of 2- to 8-yearold grass-clover ley led to decreased $\mathrm{N}$ leaching in studies of Eriksen et al. (2004), but Hansen et al. (2005) did not find any significant difference in $\mathrm{N}$ leaching after 1- or 10-year-old grass-white clover ley. This indicates that organic $\mathrm{N}$ mineralises more easily the younger the perennial plants are. In Finland, Känkänen et al. (1998) have studied N leaching risk after 1-year-old green manure grass-red clover leys and Turtola et al. (2003) after 2-year-old grass-red clover leys in conventional and organic cutting systems with manure, but comparisons of leys of different ages have not been done, nor has the effect of ploughing time been studied in organic farming conditions.

$\mathrm{N}$ use efficiency (NUE) is one way to measure the apparent recovery efficiency of applied $\mathrm{N}$ (Cassman et al. 1998). Usually it is calculated as the difference in $\mathrm{N}$ uptake between fertilised and unfertilised plots. However, it may also be calculated as the slope of the regression of the crop $\mathrm{N}$ uptake versus the applied fertiliser. This analysis has been used only rarely in situations where the input of $\mathrm{N}$ is from organic sources as BNF (Mosier et al. 2004).

The objective of the present study was to determine the residual effect of organic $\mathrm{N}$ from red 
Vol. 17 (2008): 73-87.

clover-based ley on organic farming. We studied the impact of the age, yield, BNF amount, total $\mathrm{N}$ content and $\mathrm{C}: \mathrm{N}$ of the ley on the yield, $\mathrm{N}$ uptake and NUE of two subsequent cereals. The content of mineral $\mathrm{N}$ in deeper soil $(30-90 \mathrm{~cm})$ was studied to determine the risk for $\mathrm{N}$ leaching. In addition, ploughing time combined with different subsequent crops was tested for its influence on soil mineral N. Field experiments were conducted at two sites with different climatic and soil conditions. These results will help farmers plan their crop rotations and farming practices to utilise clover-rich leys most effectively, with minimal nitrogen losses to the environment.

\section{Materials and methods}

\section{The experimental sites}

Four field experiments were started in 1994 at two locations in Finland, with two fields in each. The locations had different climatic and soil conditions as well as different cultivation histories. The locations were Juva in eastern Finland (61 $\left.{ }^{\circ} 5^{\prime} \mathrm{N} 27^{\circ} 5^{\prime} \mathrm{E}\right)$ and Mietoinen in south-western Finland $\left(60^{\circ} 3^{\prime} \mathrm{N}\right.$ $\left.21^{\circ} 4^{\prime} \mathrm{E}\right)$. In Juva, the sandy soil was tentatively classified as Dystric Regosol (FAO 2006) in both fields with moderate organic matter (OM) content. The nutrient status was good or moderate according to Finnish soil classification system (Vuorinen and Mäkitie 1955, Table 1). The fields had been under organic farming since 1987, with crop rotation including red clover-based leys, cereals and vetches (Vicia villosa, Vicia sativa) or peas (Pisum sativum). The clayey soils in Mietoinen were tentatively classified as Vertic, Stagnic Cambisol (trial 1) and Gleyic Cambisol (trial 2) (FAO 2006) with good $\mathrm{pH}$, high phosphorus and moderate to poor potassium, calcium and magnesium content based on the Finnish soil classification system (Vuorinen and Mäkitie 1955, Table 1). The fields at Mietoinen had been farmed conventionally until 1993, which means that the plots were in the process of conversion to organic farming during the first year of the experiment and under organic farming when the cereals were grown. In both fields, red clover had been grown in leys and manure had been used regularly even before the experiments.

The experiments were arranged in two trials corresponding to the two fields in each location. Field 1 in Juva (Juva 1) had not been fertilised with manure, while field 2 (Juva 2) had. In Mietoinen, field 1 (Mietoinen 1) had a moderate level of OM, while field 2 (Mietoinen 2) had a high OM content (Table 1).

The thermal growing seasons as a long-term

Table 1. Soil plough layer $(0-25 \mathrm{~cm})$ characteristics in trials 1 and 2 in Juva and Mietoinen. Soil names are defined tentatively according to FAO (2006) classification and soil nutrients were extracted with acid (pH 4.65) ammonium acetate (Vuorinen and Mäkitie 1955).

\begin{tabular}{|c|c|c|c|c|c|c|c|c|c|}
\hline \multirow[t]{2}{*}{ Trial } & \multirow[t]{2}{*}{ Soil name } & \multirow[t]{2}{*}{ Texture } & \multirow{2}{*}{$\begin{array}{c}\text { Clay } \\
\%\end{array}$} & \multirow{2}{*}{$\begin{array}{c}\text { Organic } \mathrm{C} \\
\%\end{array}$} & \multirow[t]{2}{*}{$\mathrm{pH}_{\mathrm{H} 2 \mathrm{O}}$} & $\mathrm{P}$ & $\mathrm{K}$ & $\mathrm{Ca}$ & $\mathrm{Mg}$ \\
\hline & & & & & & \multicolumn{4}{|c|}{$\mathrm{mg} \mathrm{l}^{-1}$ soil } \\
\hline Juva 1 & $\begin{array}{l}\text { Dystric } \\
\text { Regosol }\end{array}$ & Sandy loam & 3 & 1.6 & 6.6 & 26 & 140 & 1610 & 156 \\
\hline Juva 2 & $\begin{array}{l}\text { Dystric } \\
\text { Regosol }\end{array}$ & Sandy loam & 3 & 2.0 & 6.5 & 24 & 171 & 2045 & 114 \\
\hline Mietoinen 1 & $\begin{array}{l}\text { Vertic, } \\
\text { Stagnic } \\
\text { Cambisol }\end{array}$ & Clay loam & $15-30^{\dagger}$ & $3-6^{\dagger}$ & 6.7 & 37 & 134 & 1837 & 67 \\
\hline Mietoinen 2 & $\begin{array}{l}\text { Gleyic } \\
\text { Cambisol }\end{array}$ & Gyttja clay & $>50^{\dagger}$ & $6-12^{\dagger}$ & 6.5 & 28 & 170 & 3442 & 97 \\
\hline
\end{tabular}

'Determined by finger assessment 
Nykänen, A. et al. Residual effect of clover-rich leys

average (1971-2000) is 162 days in Juva and 181 days in Mietoinen. The average long-term rainfall (1961-1990) from May to October had been 370 $\mathrm{mm}$ in both locations. However, during the present experiment, the annual precipitation in Juva was 40-70 mm lower than the average, except in 1998, when the precipitation was very high $(430 \mathrm{~mm})$. In Mietoinen the precipitation was exceptionally high in 1997 (440 mm), and the year 1996 was very dry, with precipitation of only $280 \mathrm{~mm}$.

\section{Field experiments}

The trials were designed as split-plot experiments with two main plots and four sub-plots $\left(4 \times 10 \mathrm{~m}^{2}\right)$ with three blocks (replicates). The main plots were planted with two different cereal species, grown subsequent to leys, ploughing of the ley timed appropriately for the crop planted. Main plot A was winter rye with early ploughing of the ley (August), and main plot B was spring wheat with late ploughing (October in Mietoinen, as spring ploughing is not recommended for the clay soil, or the next May in Juva). In Juva, the fields were ploughed in autumn and spring according to these main plots after first cereals after leys for spring oats, but in Mietoinen all plots were ploughed in October for spring oats. Sub-plots comprised of four crop rotations, which consisted of leys with 1-, 2- or 3-year-old red clover-grass or two or three years spring cereal monoculture as a reference.

Field trials started in 1994 (Table 2). In both locations, trial 1 was performed in a field where a red clover-grass ley had been undersown with spring barley as a nurse crop in 1993. Trial 2 was performed in a field where a 1-year-old-ley was grown in 1993 and the ley for trial 2 was ploughed under in May 1994 for all crop rotations except one, which continued as a 2-year-old ley in 1994. In 1997 the first year residual effect of ley was measured in winter rye or spring wheat in trial 1 and in 1996 in trial 2. Similarly, the second cereal (spring oats) after ley incorporation was grown in 1998 in trial 1 and in 1997 in trial 2. This means that trials 1 and 2, situated in different fields, were cultivated in different calendar years with different climatical conditions (Table 2).

The seed mixture of the ley consisted of $5 \mathrm{~kg}$ $\mathrm{ha}^{-1}$ of red clover (Trifolium pratense cv. Bjursele), $10 \mathrm{~kg} \mathrm{ha}^{-1}$ of timothy (Phleum pratense cv. Bottnia 2) and $6 \mathrm{~kg} \mathrm{ha}^{-1}$ of meadow fescue (Festuca pratensis cv. Kalevi). The number of seeds sown was $600 \mathrm{~m}^{-2}$ for spring wheat (Triticum aestivum, $\mathrm{cv}$. Heta) and $500 \mathrm{~m}^{-2}$ for spring barley (Hordeum vulgare, cv. Arra), spring oats (Avena sativa, cv. Veli), and winter rye (Secale cereale, cv. Voima). No manure or any other fertilisers were used during the experiments. Some perennial weeds were

Table 2. Crop rotations (sub-plots) in trials 1 and 2 in Juva and Mietoinen.

\begin{tabular}{|c|c|c|c|c|c|c|c|}
\hline Trial & $\begin{array}{l}\text { Sub- } \\
\text { plot }\end{array}$ & 1993 & 1994 & 1995 & 1996 & 1997 & 1998 \\
\hline \multirow{4}{*}{$\begin{array}{l}\text { Juva } 1 \\
\text { Mietoinen } 1\end{array}$} & 1 & Barley (us) & Oats & Oats & Barley & Rye or wheat & Oats \\
\hline & 2 & Barley (us) & Oats & Barley (us) & Ley 1 & Rye or wheat & Oats \\
\hline & 3 & Barley (us) & Barley (us) & Ley 1 & Ley 2 & Rye or wheat & Oats \\
\hline & 4 & Barley (us) & Ley 1 & Ley 2 & Ley 3 & Rye or wheat & Oats \\
\hline \multirow{4}{*}{$\begin{array}{l}\text { Juva } 2 \\
\text { Mietoinen } 2\end{array}$} & 1 & Ley $1^{\dagger}$ & Oats & Barley & Rye or wheat & Oats & \\
\hline & 2 & Ley $1^{\dagger}$ & Barley (us) & Ley 1 & Rye or wheat & Oats & \\
\hline & 3 & Ley $1^{\dagger}$ & Ley 1 & Ley 2 & Rye or wheat & Oats & \\
\hline & 4 & Ley 1 & Ley 2 & Ley 3 & Rye or wheat & Oats & \\
\hline
\end{tabular}

us $=$ Ley undersown, ${ }^{\dagger}$ Ley was ploughed under in May 1994. The mentioned cereals are spring cereals except winter rye 
Vol. 17 (2008): 73-87.

removed by hand during the experiments, but weed infestation was rather high especially in trial 1 . No control of pests or diseases was done and no severe infections were observed.

\section{Plant and soil samples}

The dry matter yields, clover contents and total $\mathrm{N}$ contents of the harvested biomass of leys were determined and the results have been reported by Nykänen et al. (2000). Total N yields in harvested biomass of the leys were calculated based on those results (Table 3). The amount of BNF in harvested biomass was also calculated from those results using a formula developed by Carlsson \& Huss-Danell (2003): BNF $\left(\mathrm{kg} \mathrm{ha}^{-1} \mathrm{yr}^{-1}\right)=$ clover dry matter yield $\left(\mathrm{kg} \mathrm{ha}^{-1} \mathrm{yr}^{-1}\right) \times 0.026+7$. Total $\mathrm{N}$ incorporated into the soil (stubble, roots and crop residues) was calculated from harvested $\mathrm{N}$ yield and BNF according to Hansson (1987) and Høgh-Jensen et al. (2004) by multiplying harvested $\mathrm{N}$ yield and $\mathrm{BNF}$ amounts by 0.6 assuming that about $40 \%$ of the total biomass (above and below ground) is in stubble, roots and crop residues as well as in the re-growth after second harvest. No difference between leys of different ages was not made in this calculation, as there were no clear results in literature for that. Clover content, $\mathrm{N}$ content and $\mathrm{C}: \mathrm{N}$ in the incorporated biomass was calculated as a mean, weighted by the corresponding ley yield of the first and second cut (Table 3 ).

In Juva, root samples of $20 \times 20 \times 30 \mathrm{~cm}^{3}$ were taken from some plots for $\mathrm{C}: \mathrm{N}$ determinations before ley ploughing. Roots were washed and dried at $60{ }^{\circ} \mathrm{C}$ overnight and they were analysed for total $\mathrm{N}$ and $\mathrm{C}$ content by a LECO ${ }^{\circledR}$ CNS- 1000 Analyzer. The results are not very precise, as it is very difficult to take a representative sample. Some idea can be obtained, however, as $\mathrm{C}: \mathrm{N}$ varied from 14 to 24 , giving an average value of 20 , with no difference between leys of different ages.

Cereals were harvested by a combine harvester from an area of $1.5 \times 10 \mathrm{~m}^{2}$. In Mietoinen the spring oats crop in trial 1 in 1998 was not harvested because of technical problems. The grains and straw were weighed and dried at $105^{\circ} \mathrm{C}$ overnight, and the dry matter yields were calculated. Samples for total $\mathrm{N}$ and $\mathrm{C}$ were dried at $60^{\circ} \mathrm{C}$ overnight. The total $\mathrm{N}$ uptake of cereal seeds and straw was calculated for the first and second cereal after leys, together with the cumulative $\mathrm{N}$ uptake for these two cereals. NUE was calculated over treatments i.e. cereal yields after leys of different ages by regression analyses as the slope of grain $\mathrm{N}$ uptake versus the amount of $\mathrm{N}$ incorporated into the soil.

Nitrate $\left(\mathrm{NO}_{3}^{-}-\mathrm{N}\right)$ and ammonium $\left(\mathrm{NH}_{4}^{+}-\mathrm{N}\right)$ nitrogen were analysed from the soil in depths of 0-30 cm, 30-60 cm and 60-90 cm after breaking up the leys, i.e. during cereal cultivation. Samples were taken in May (the beginning of the growing season), August (at harvest) and November (before first frost), as well as at several times during the growing season from the uppermost soil layer. The samples were stored frozen until they were extracted with $2 \mathrm{M} \mathrm{KCl}$. The filtrate was analysed with a

Table 3. Ley yields, total nitrogen $(\mathrm{N})$ and $\mathrm{N}$ from biological nitrogen fixation $(\mathrm{BNF}-\mathrm{N})\left(\mathrm{kg} \mathrm{ha}^{-1}\right)$ incorporated into the soil and $\mathrm{C}: \mathrm{N}$ of ley yields before cereals in trials 1 and 2 in Juva and Mietoinen. Also number of observations (n) is showed for each trial.

\begin{tabular}{llcccc}
\hline Trial & $\mathrm{n}$ & Ley yield & Total N & BNF-N & Ley C:N \\
\hline Juva 1 & 18 & 5100 & 79 & 51 & 18 \\
Juva 2 & 18 & 6900 & 88 & 52 & 22 \\
Mietoinen 1 & 14 & 6800 & 84 & 67 & 23 \\
Mietoinen 2 & 12 & $6500 / 9700^{\dagger}$ & $94 / 145^{\dagger}$ & 49 & 20 \\
\hline
\end{tabular}

${ }^{\dagger}$ values for main plots A / B 
Nykänen, A. et al. Residual effect of clover-rich leys

Scalar autoanalyser (air segmented flow analyser, photometric detection) and converted into $\mathrm{kg} \mathrm{ha}^{-1}$ (Esala 1991, p. 253).

\section{Statistical analyses}

The yield and $\mathrm{N}$ uptake data of cereals were gathered from all trials with the split-plot experimental design. All trials were analysed together using the following statistical model, taking into account the fact that the trials took place in two locations:

$\mathrm{y}_{\mathrm{ijklm}}=\mu+\mathrm{T}_{\mathrm{m}}\left(\mathrm{L}_{\mathrm{l}}\right)+\mathrm{L}_{1}+\mathrm{B}_{\mathrm{k}}\left(\mathrm{L}_{1} \mathrm{~T}_{\mathrm{m}}\right)+\mathrm{M}_{\mathrm{i}}+\mathrm{ML}_{\mathrm{il}}+$ $\mathrm{MT}_{\mathrm{im}}\left(\mathrm{L}_{1}\right)+\mathrm{MB}_{\mathrm{ik}}\left(\mathrm{L}_{1} \mathrm{~T}_{\mathrm{m}}\right)+\mathrm{S}_{\mathrm{j}}+\mathrm{SL}_{\mathrm{jl}}+\mathrm{MS}_{\mathrm{ij}}+\mathrm{MSL}_{\mathrm{ijk}}$ $+\varepsilon_{\mathrm{ijklm}}$

where $\mu$ is the intercept and $y_{i j k l m}$ is the nitrogen yield $(\mathrm{kg} / \mathrm{ha})$ for the $\mathrm{i}^{\text {th }}$ main plot treatment $(\mathrm{i}=1,2)$ and $\mathrm{j}^{\text {th }}$ sub-plot treatment $(\mathrm{j}=1,2,3,4)$ in the $\mathrm{k}^{\text {th }}$ block $(\mathrm{k}=1,2,3)$ and $\mathrm{l}^{\text {th }}$ location ( $\mathrm{l}=\mathrm{Juva}$, Mietoinen $)$. Both locations had two trials $(\mathrm{m}=1,2)$ and $\mathrm{T}_{\mathrm{m}}\left(\mathrm{L}_{1}\right)$ is the random effect of the $\mathrm{m}^{\text {th }}$ trial, nested $\mathrm{l}^{\text {th }}$ location, while $\mathrm{B}_{\mathrm{k}}\left(\mathrm{L}_{1} \mathrm{~T}_{\mathrm{m}}\right)$ and $\mathrm{MB}_{\mathrm{ik}}\left(\mathrm{L}_{1} \mathrm{~T}_{\mathrm{m}}\right)$ are the random effect of block and main-plot error, respectively, and all four trials have their own blocks. $\mathrm{L}_{1}, \mathrm{M}_{\mathrm{i}}, \mathrm{S}_{\mathrm{j}}, \mathrm{ML}_{\mathrm{il}}$, $\mathrm{SL}_{\mathrm{j}}, \mathrm{MS}_{\mathrm{ij}}$ and $\mathrm{MSL}_{\mathrm{ijk}}$ represent the fixed effects of the location, main plot treatment, sub-plot treatment and their interactions, respectively. The model used allows the differences between main plot treatments, sub-plot treatments and their interactions to vary from trial to trial within both locations by the random effects of $\mathrm{MT}_{\mathrm{im}}\left(\mathrm{L}_{1}\right), \mathrm{ST}_{\mathrm{jm}}\left(\mathrm{L}_{1}\right)$ and $\mathrm{MST}_{\mathrm{ijm}}\left(\mathrm{L}_{1}\right) \cdot \varepsilon_{\mathrm{ijklm}}$ is residual error (= sub-plot error). All random variables are assumed to be independent and normally distributed with 0 means and their own variances. The parameters of the model for both locations were estimated by using the restricted maximum likelihood (REML) estimation method. The different years were analysed separately.

The accuracy of the model used was examined using residual plots. Normality of the residuals was investigated using a box plot (Tukey 1977). Tests for differences between age and year groups were made with contrasts. Degrees of freedom of tests were calculated using a Kenward-Roger method.
The analyses were done using the MIXED procedure of SAS software version 9.1.3.

The yield data of leys cultivated before cereals were divided according to the different trials and main plots. Subsequently Pearson correlation analysis was used for the identification of associations between the ley yield parameters (ley yields, $\mathrm{BNF}$ and $\mathrm{N}$ amounts incorporated into the soil as well as $\mathrm{C}: \mathrm{N}$ in the incorporated biomass) and cereal yields, $\mathrm{N}$ uptake and NUE. Correlation analyses were done separately for each trial, main plot and cereal species.

Examination of the data showed that the distribution of $\mathrm{NO}_{3}^{-}-\mathrm{N}$ had a positive skew, i.e. the mean was higher than the median and there was a relatively long upper tail. After square-root transformation, the distribution was quite normal. All the estimates presented were transformed back to the original scale, but it was not possible to transform the standard error of estimates. The magnitude of variation in measurement times clearly varied for the $\mathrm{NO}_{3}{ }^{-} \mathrm{N}$ and $\mathrm{NH}_{4}^{+}-\mathrm{N}$ data. Therefore, the statistical model was simplified by analysing all measurement times and trials separately. The standard analysis of variance model was used to analyse split-plot data (Gomez and Gomez 1984).

\section{Results}

\section{Cereal yields}

The grain yields of winter rye after leys of different ages were about $1800 \mathrm{~kg} \mathrm{ha}^{-1}$ in Juva and $2500 \mathrm{~kg}$ $\mathrm{ha}^{-1}$ in Mietoinen, giving an average yield of 2100 $\mathrm{kg} \mathrm{ha}^{-1}$. The yields of spring wheat were 2400 , 3300 and $2700 \mathrm{~kg} \mathrm{ha}^{-1}$, respectively. The pre-crop (cereal or leys of different ages) had no statistically significant effect on the yields i.e. leys had no residual effect on cereal yields. All cereal yields were higher in Mietoinen than in Juva, but the difference between cereal species in each location was small and statistically non-significant (Fig. 1).

In Juva the yields of spring oats after winter rye 
Vol. 17 (2008): 73-87.

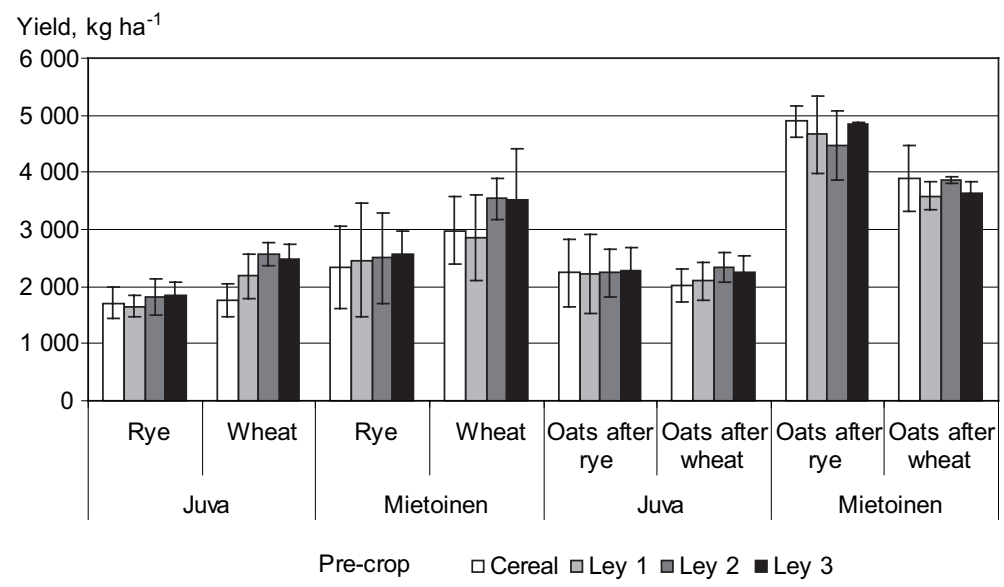

Fig. 1. Cereal yields (15\% moisture) of winter rye or spring wheat, followed by spring oats with various leys or cereal monoculture as pre-crops in Juva and Mietoinen. Line segments show standard deviations. There were no statistically significant differences $(p>0.05)$ between cereals and leys of different ages as pre-crops. or spring wheat were $2200 \mathrm{~kg} \mathrm{ha}^{-1}$ and they were not affected by either the pre-crops (winter rye or spring wheat) or the pre-pre-crops (cereals or leys of different ages) (Fig. 1). In Mietoinen the yields of spring oats were $2000 \mathrm{~kg} \mathrm{ha}^{-1}$ higher than in Juva and $1000 \mathrm{~kg} \mathrm{ha}^{-1}$ higher (though this difference was not statistically significant) after winter rye than after spring wheat, but there were no differences in the effects of the pre-pre-crops (Fig. 1).

Based on the correlation analyses, the yields of winter rye and spring wheat after leys were influenced by the ley yields as well as N and BNF-N amounts in the incorporated biomass in Juva (Table 4.). In Juva 1 trial, the cereal yields were higher after higher ley yields and BNF-N and $\mathrm{N}$ amount incorporated into the soil. In Juva 2 trial, the influence was quite the opposite, as the correlations were negative. In Mietoinen, only a negative correlation was found in Mietoinen 2 trial between ley and cereal yields. There was a positive correlation between $\mathrm{C}: \mathrm{N}$ of the previous ley yield, i.e. incorporated biomass, and the yields of winter rye and spring wheat in trial Juva 2 (Table 4).

In Juva, yields for oats grown in second year after leys showed a positive correlation with both ley yields and $\mathrm{N}$ amount in biomass. In Mietoinen these correlations were negative (Table 4).

Table 4. Correlation coefficients of cereal yields to ley yields, total nitrogen $(\mathrm{N})$ and $\mathrm{N}$ from biological nitrogen fixation (BNF-N) amounts incorporated into the soil and C:N of previous ley yields in trials 1 and 2 in Juva and Mietoinen. Only statistically significant figures are shown for clarity.

\begin{tabular}{|c|c|c|c|c|c|c|c|c|}
\hline \multirow[b]{2}{*}{ Trial } & \multicolumn{4}{|c|}{$\begin{array}{l}\text { First year after ploughing } \\
\text { Winter rye or spring wheat }\end{array}$} & \multicolumn{4}{|c|}{$\begin{array}{l}\text { Second year after ploughing } \\
\text { Spring oats }\end{array}$} \\
\hline & Ley yield & Total N & BNF-N & Ley C:N & Ley yield & Total N & BNF-N & Ley C:N \\
\hline Juva 1 & $0.49 *$ & $0.67 * *$ & $0.56^{*}$ & & $0.50 *$ & $0.64 * *$ & & \\
\hline Juva 2 & $-0.52 *$ & $-0.69 * *$ & $-0.50^{*}$ & $0.61 * *$ & $0.60 * *$ & & & \\
\hline Mietoinen 1 & & & & & n.d. & n.d. & n.d. & n.d. \\
\hline Mietoinen 2 & $-0.60 *$ & & & & $-0.79 * *$ & $-0.61 *$ & & \\
\hline
\end{tabular}

Statistical significance: $* * * p<0.001 ; * * p<0.01 ; * p<0.05$, n.d. $=$ no data 
Nykänen, A. et al. Residual effect of clover-rich leys

\section{Nitrogen uptake of cereals}

The total $\mathrm{N}$ uptake of spring wheat was higher after leys than after cereal monoculture $(p<0.05)$ in Juva. The $\mathrm{N}$ uptake was $62 \mathrm{~kg} \mathrm{ha}^{-1}$ after leys, which was $20 \mathrm{~kg} \mathrm{ha}^{-1}$ higher than after cereal monoculture, giving a residual effect of $20 \mathrm{~kg} \mathrm{ha}^{-1}$ of $\mathrm{N}$ for grassclover leys. No influence of the age of the ley was discovered. In Mietoinen, the $\mathrm{N}$ uptake of winter rye and spring wheat as well as the $\mathrm{N}$ uptake of winter rye in Juva were also higher after leys than after cereal monoculture, but the increase in uptake was not statistically significant (Fig. 2). The total N uptake of spring oats was not affected by pre-crops or pre-pre-crops. The average uptake was $45 \mathrm{~kg} \mathrm{ha}^{-1}$ in Juva and $97 \mathrm{~kg} \mathrm{ha}^{-1}$ in Mietoinen (Fig. 2).

The $\mathrm{N}$ uptake of all cereals was explained by higher total $\mathrm{N}$ amounts in the incorporated biomass in Juva. An exception was noticed for winter rye and spring wheat $\mathrm{N}$ uptake in Juva 2 trial, where the higher $\mathrm{N}$ uptake was explained by lower $\mathrm{N}$ in the incorporated biomass. Higher $\mathrm{N}$ uptake of oats in the second year after the ley correlated positively with a higher ley yield. In Juva 2 trial, the higher $\mathrm{C}: \mathrm{N}$ positively influenced the $\mathrm{N}$ uptake of the first cereals after ley incorporation, but it had a negative influence on uptake in Mietoinen 2 trial (Table 5).

\section{Nitrogen use efficiency}

The data were also divided into trials and main plots for the calculation of NUE. In Juva the NUE of winter rye (30\%) was lowest, and was highest in the case of spring wheat $(52 \%)$, with spring oats (41\%) having an intermediate value (Table 6). In Mietoinen, the NUEs were $49 \%, 59 \%$ and $64 \%$ for winter rye, spring wheat and spring oats, respectively. The higher NUE in Mietoinen was in most cases explained by higher yields, as the incorporated $\mathrm{N}$ was nearly identical, $80-90 \mathrm{~kg} \mathrm{~N}$ $\mathrm{ha}^{-1}$, in both locations except in main plot B (before spring wheat) in trial Mietoinen 2, where it was $146 \mathrm{~kg} \mathrm{~N} \mathrm{ha}^{-1}$ (Table 3). In Mietoinen, the overall variation was high and there were larger differences between trials and even between the main plots than between the cereal species. This could be explained by the differences in cereal yields (high for winter rye and spring oats in Mietoinen 2 trial (main plot A), resulting in higher NUE) and $\mathrm{N}$ amounts in the incorporated biomass (high for spring wheat in trial 2, resulting in low NUE) (Table 6).

The NUE of the first cereal crop after ley incorporation was influenced by ley yield as well as the amounts of $\mathrm{N}$ and BNF-N incorporated into the soil in trial 2, in both Juva 2 and Mietoinen 2 (Table 7).
Fig. 2. Total nitrogen (totN) uptake of winter rye or spring wheat, followed by spring oats with various leys or cereal monoculture as pre-crops in Juva and Mietoinen. $\left({ }^{*}=p<0.05\right.$; NS $=p>0.05$, line segments show standard deviations.)

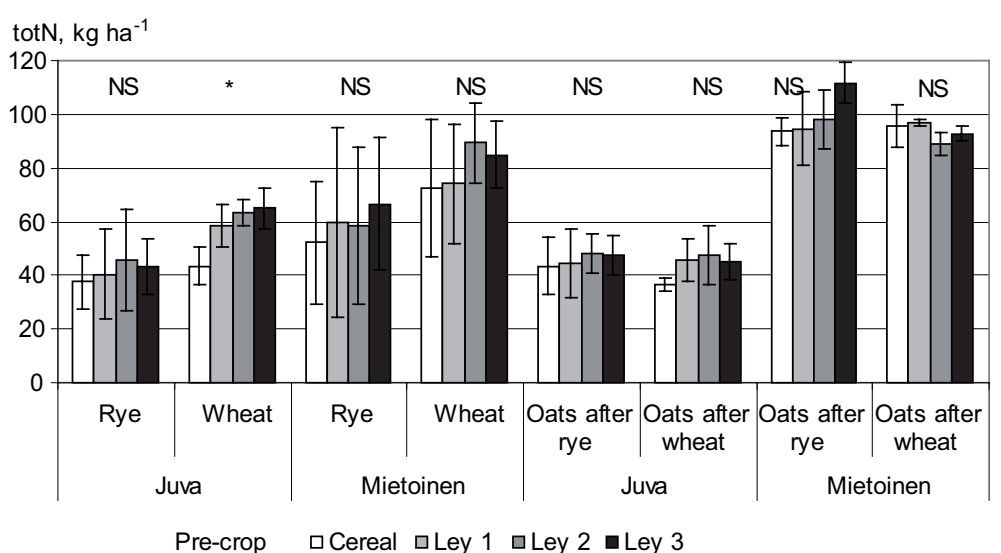


Vol. 17 (2008): 73-87.

Table 5. Correlation coefficients of cereal nitrogen uptake (grains and straw) to ley yields, total nitrogen (N) and $\mathrm{N}$ from biological nitrogen fixation (BNF-N) amounts incorporated into the soil and C:N of previous ley yields in trials 1 and 2 in Juva and Mietoinen. Only statistically significant figures are shown for clarity.

\begin{tabular}{|c|c|c|c|c|c|c|c|c|}
\hline \multirow[b]{2}{*}{ Trial } & \multicolumn{4}{|c|}{$\begin{array}{l}\text { First year after ploughing } \\
\text { Winter rye or spring wheat } \\
\end{array}$} & \multicolumn{4}{|c|}{$\begin{array}{l}\text { Second year after ploughing } \\
\text { Spring oats }\end{array}$} \\
\hline & Ley yield & Total N & BNF-N & Ley C:N & Ley yield & Total N & BNF-N & Ley C:N \\
\hline Juva 1 & & $0.6^{* *}$ & & & $0.54^{*}$ & $0.62^{* *}$ & & \\
\hline Juva 2 & & $-0.5^{*}$ & $-0.51^{*}$ & $0.47^{*}$ & $0.75^{* * *}$ & $0.69^{* * *}$ & & \\
\hline Mietoinen 1 & & & & & n.d. & n.d. & n.d. & n.d. \\
\hline Mietoinen 2 & & & & $-0.61^{*}$ & & & & \\
\hline
\end{tabular}

Table 6. Nitrogen use efficiency (NUE) and mean NUE of two subsequent cereals (winter rye or spring wheat and spring oats thereafter) after leys in trials 1 and 2 in Juva and Mietoinen.

\begin{tabular}{|c|c|c|c|c|}
\hline Trial & $\begin{array}{l}\text { NUE, \% } \\
\text { Winter rye }\end{array}$ & Spring wheat & Spring oats & Mean \\
\hline Juva 1 & 0.31 & 0.50 & 0.37 & 0.39 \\
\hline Juva 2 & 0.29 & 0.53 & 0.44 & 0.42 \\
\hline Mean, Juva & 0.30 & 0.52 & 0.41 & 0.41 \\
\hline Mietoinen 1 & 0.40 & 0.78 & n.d. & 0.59 \\
\hline Mietoinen 2 & 0.57 & 0.39 & $0.84 / 0.44^{\dagger}$ & 0.56 \\
\hline Mean Mietoinen & 0.49 & 0.59 & 0.64 & 0.58 \\
\hline Mean total & 0.40 & 0.55 & 0.48 & 0.48 \\
\hline
\end{tabular}

Table 7. Correlation coefficients of nitrogen use efficiency (NUE) of two subsequent years after leys to ley yields, total nitrogen $(\mathrm{N})$ and $\mathrm{N}$ from biological nitrogen fixation (BNF-N) amounts incorporated into the soil and C:N of previous ley yields in trials 1 and 2 in Juva and Mietoinen. Only statistically significant figures are shown for clarity.

\begin{tabular}{|c|c|c|c|c|c|c|c|c|}
\hline \multirow[b]{2}{*}{ Trial } & \multicolumn{4}{|c|}{$\begin{array}{l}\text { First year after ploughing } \\
\text { Winter rye or spring wheat }\end{array}$} & \multicolumn{4}{|c|}{$\begin{array}{l}\text { Second year after ploughing } \\
\text { Spring oats }\end{array}$} \\
\hline & Ley yield & Total N & BNF-N & Ley C:N & Ley yield & Total N & BNF-N & $\begin{array}{l}\text { Ley } \\
\mathrm{C}: \mathrm{N}\end{array}$ \\
\hline Juva 1 & & & & & $-0.57^{* *}$ & $-0.58^{* *}$ & $-0.59^{* *}$ & \\
\hline Juva 2 & $-0.69^{* * *}$ & $-0.83^{* * *}$ & $-0.57^{* *}$ & $0.66^{* *}$ & & & & \\
\hline Mietoinen 1 & & & & & n.d. & n.d. & n.d. & n.d. \\
\hline Mietoinen 2 & $-0.95^{* * *}$ & $-0.92^{* * *}$ & $-0.66^{*}$ & & $-0.96^{* * * *}$ & $-0.89^{* * *}$ & $-0.64^{*}$ & \\
\hline
\end{tabular}

Statistical significance: ${ }^{* * *}(p<0.001) ;{ }^{* *}(p<0.01) ;{ }^{*}(p<0.05)$, n.d. $=$ no data.

The NUE of spring oats, the second cereal after ley incorporation, was also influenced by these factors in Juva 1 trial and in Mietoinen 2 trial. The influence was negative in all these cases. The $\mathrm{C}: \mathrm{N}$ had a positive influence on the NUE of first cereal crop after ley incorporation in Juva 2 trial.

\section{Nitrogen leaching risk}

Statistically significant differences in concentrations of $\mathrm{NO}_{3}^{-}-\mathrm{N}$ or $\mathrm{NH}_{4}^{+}-\mathrm{N}$ in the soil, between leys of different ages and cereal monoculture were only occasionally seen and there was no clear explana- 
Nykänen, A. et al. Residual effect of clover-rich leys

tion for those differences. This is why we present general figures about the amounts of mineral $\mathrm{N}$ in deeper soil layers, indicating $\mathrm{N}$ leaching risk in different locations and after different ley incorporation management regimens.

The $\mathrm{NO}_{3}^{-}-\mathrm{N}$ amounts in the plough layer varied from $1 \mathrm{~kg} \mathrm{ha}^{-1}$ to $16 \mathrm{~kg} \mathrm{ha}^{-1}$ in the two years of cereal crops after ley incorporation in both locations. In Juva, the $\mathrm{NH}_{4}^{-}-\mathrm{N}$ amounts in the plough layer were $15-35 \mathrm{~kg} \mathrm{ha}^{-1}$ in Juva 1 trial and 5-15 $\mathrm{kg} \mathrm{ha}^{-1}$ in Juva 2 trial. In Mietoinen, the amounts in the two trials were $1-15 \mathrm{~kg} \mathrm{ha}^{-1}$ and 9-22 $\mathrm{kg} \mathrm{ha}^{-1}$, respectively.

In Juva, the mineral $N$ at a depth of 30-90 cm was not influenced by the cereal species planted subsequent to leys (Fig. 3). Over second year after ley incorporation, the ploughing in the soil in October (A) instead of next May (B) incresed the soil mineral $\mathrm{N}$ content by $0.5-3 \mathrm{~kg} \mathrm{ha}^{-1}$. The highest values of $\mathrm{NO}_{3}^{-}-\mathrm{N}$ were measured in May after snow-melt runoff, where as the highest values of $\mathrm{NH}_{4}^{+}-\mathrm{N}$ were measured in November after the growing season (data not shown). The mineral $\mathrm{N}$ values in these deeper soil layers in Juva were 3-11 $\mathrm{kg} \mathrm{ha}^{-1}$ (Fig. 3), which indicates quite a low risk of $\mathrm{N}$ leaching.

In Mietoinen, the highest values for mineral $\mathrm{N}$ in soil layers of 30-90 cm were found in November, after ploughing in the ley for spring wheat, and always in May (Fig.4.). In the clay soils of
Mietoinen, spring ploughing is not possible. Thus, the effect of ploughing time could only be observed in the first year after ley incorporation. Bigger differences could be found between the fields with different soil OM content. After ploughing the ley under in trial 2, which has higher soil OM content, the mineral $\mathrm{N}$ amounts under winter rye were 27 $\mathrm{kg} \mathrm{ha}^{-1}$ in November, and mineral $\mathrm{N}$ of bare soil before spring wheat was $17 \mathrm{~kg} \mathrm{ha}^{-1}$. In Mietoinen 1 trial, which has lower OM content, the corresponding amounts of mineral $\mathrm{N}$ were 9 and $4 \mathrm{~kg} \mathrm{ha}^{-1}$, respectively. In the second year, when spring oats was cultivated, there was no difference between the main plots as there was no difference in ploughing times in Mietoinen. The values were $5-25 \mathrm{~kg} \mathrm{ha}^{-1}$, which indicates a two fold greater risk of $\mathrm{N}$ leaching compared to the Juva fields (Fig. 4 )

\section{Discussion}

\section{Cereal yields}

The amount and composition of the incorporated grass-clover ley influenced cereal yields after leys, as had been also observed by Høgh-Jensen and Schjoerring (1997). It is important to know the
Fig. 3. Mineral nitrogen $\left(\mathrm{N}_{\min }\right)$ amounts in soil depth $30-90 \mathrm{~cm}$ in Juva after ley incorporation. $(\mathrm{A}=$ winter rye with ploughing in August followed by spring oats with ploughing in October, $\mathrm{B}=$ spring wheat with ploughing in May followed by spring oats with ploughing in May).

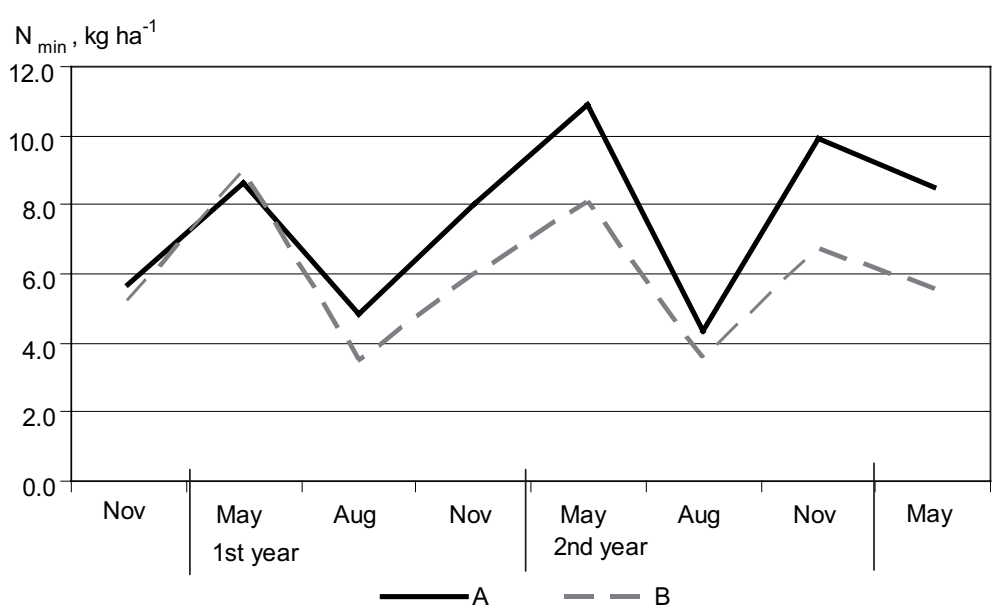


Vol. 17 (2008): 73-87.

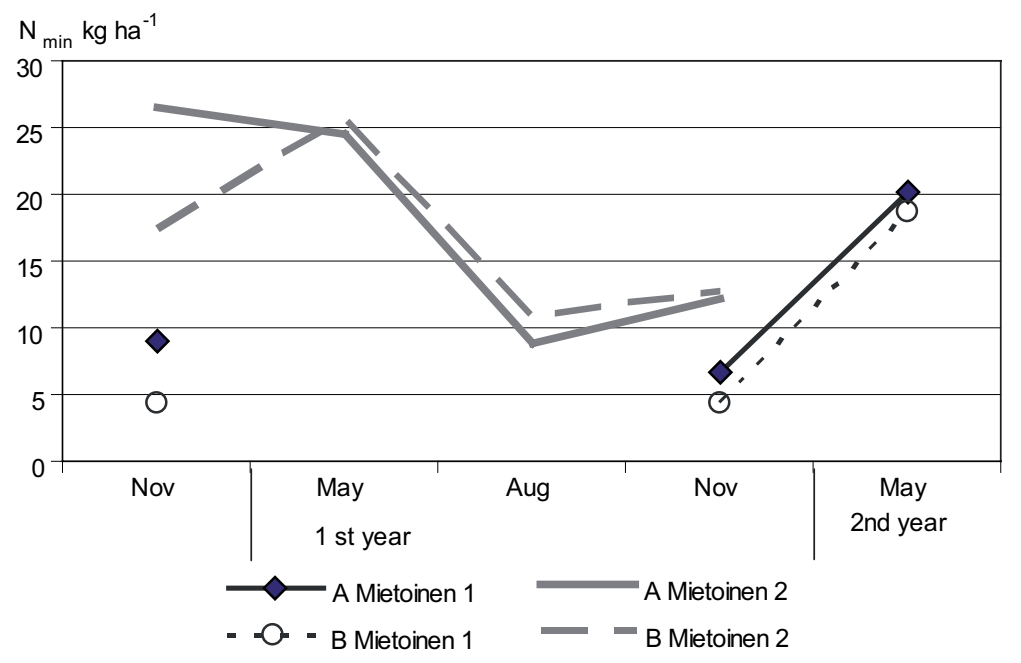

Fig. 4. Mineral nitrogen $\left(\mathrm{N}_{\min }\right)$ amounts in soil depth $30-90$ $\mathrm{cm}$ in Mietoinen after ley incorporation in trials Mietoinen 1 and Mietoinen 2. $(\mathrm{A}=$ winter rye with ploughing in August followed by spring oats with ploughing in October, $\mathrm{B}=$ spring wheat with ploughing in October followed by spring oats with ploughing in October). cropping history (manuring, legume cultivation) and analyse the soil (C, N, OM) to adjust cultivation practices for the demands of the crop, as was concluded by Hansen et al. (2005). In trial 1, both in Juva 1 and Mietoinen 1, the cereal yields were higher when ley yields, BNF-N and $\mathrm{N}$ amount incorporated into the soil were higher. In trial 2, the influence of these factors was quite the opposite in the first year after leys. Similarly, this inverse effect was seen in the second year in Mietoinen 2, but not in Juva 2.

Haynes (1986) has defined the decomposition of incorporated biomass to have three phases: leaching of water soluble substances, accumulation into microbial biomass and net release, when $\mathrm{N}$ is no longer limiting to microbial growth and activity. In cases of high $\mathrm{N}$ in the incorporated biomass, there is no accumulation phase. This may have occurred in trial 1 in both locations. In Juva 2 trial in, the plots reached the net release phase after one year of cereal cultivation after ley incorporation, whilst in Mietoinen 2 the plots remained in the accumulation phase during the experiment. It is possible that the microbial activity was the highest in Mietoinen 2 trial, where there was a high OM content (6-12\%) in the soil resulting in a long accumulation phase. In Juva, the microbial activity might also have been higher in trial Juva 2 than in trial Juva 1 because manure had been used in the field before our experiment.

The yields of winter rye and spring wheat after leys correlated positively with the $\mathrm{C}: \mathrm{N}$ of the previous ley yield only in Juva 2 trial. Our calculated $\mathrm{C}: \mathrm{N}$ values in the incorporated biomass were between 17 and 24. In the measurements of some root and stubble samples of the incorporated ley, we found lower concentrations in autumn than in spring for both C (30\% vs. 35\%) and N (1.2\% vs. $2 \%$ ). However, $\mathrm{C}: \mathrm{N}$ was higher in autumn (20-25) than in the spring, when $\mathrm{C}: \mathrm{N}$ was $15-20$. These measurements, although not representative, show our calculations to be in a reasonably good agreement with the actual $\mathrm{C}: \mathrm{N}$ in the incorporated biomass. According to Haynes (1986), a C:N below 20-25 in the incorporated biomass results in net mineralization of $\mathrm{N}$ in the soil. In the conditions that pertained in our trials, this critical value would be near 25 to explain the positive correlation of cereal yields and $\mathrm{C}: \mathrm{N}$ by net $\mathrm{N}$ mineralization in Juva 2 trial.

The age of the ley had no effect on the cereal yields in our experiment. This was also the case in studies of Hansen et al. (2005), where it was thought to be a result of the higher surplus of $\mathrm{N}$ in the 10-year-old ley and more easily mineralised $\mathrm{N}$ in the 1-year-old ley. This phenomenon could be 
Nykänen, A. et al. Residual effect of clover-rich leys

true for our younger leys as well. Quite surprisingly, cereal monocultures as pre-crops and prepre-crops had nearly the same, or even higher, residual effects as leys. This might be partly because of quite high infestation of annual and especially perennial weeds (Elymus repens, Sonchus arvensis, Cirsium arvense). Another reason could be low or even negative $\mathrm{N}$-balances (input of $\mathrm{N}$ from $\mathrm{BNF}$ and total $\mathrm{N}$ harvested) of leys as pre-crops, especially in Juva.

\section{Nitrogen uptake of cereals}

The correlations between $\mathrm{N}$ uptake and cereal yields were similar in all trials, which is reasonable, as $\mathrm{N}$ is quite often the growth-limiting factor in organic farming. Eriksen et al. (2006) found the grain yield and $\mathrm{N}$ uptake of spring wheat to increase with the increasing age of the ley when they compared leys that were 1, 2 and 8 years old. Johnston et al. (1994) also found the same for 1-, 2- and 3-year-old leys, but not for older leys. In our studies, the age of the ley did not have a clear influence on the yields or the $\mathrm{N}$ uptake of the subsequent two cereals. In the study of Eriksen et al. (2006) the leys were grazed and in Johnston et al. (1994) the cut plants were not removed but they were used as green manure, which means more $\mathrm{N}$ input to the field than in cutting systems like ours.

The cumulative $\mathrm{N}$ uptake of cereals for two subsequent years exceeded the incorporated biomass BNF-N in all trials. This means that if the above-ground biomass is removed from the field, as is done in the cutting systems, more $\mathrm{N}$ from outside the field is needed in addition to BNF to compensate for $\mathrm{N}$ deficiency. Manure is used as fertiliser on farms where ley yields are used as fodder.

In Juva there were differences in levels of $\mathrm{N}$ in soil plough layers between trials Juva 1 and Juva 2 . The $\mathrm{NO}_{3}^{-}-\mathrm{N}$ levels were higher in Juva 1 trial than in Juva 2 trial during the growing season after ley incorporation. $\mathrm{N}$ uptake of cereals was higher in Juva 2 trial, which could mean that for some reason the cereals in Juva 1 trial were not able to take up
$\mathrm{N}$ from the soil effectively. This might have been because of abundance of weeds, both annual and perennial. On the other hand, the precipitation was high in July 1997, when Juva 1 trial was in this phase of crop rotation, which means that soil may have been too wet for cereal growth but not wet enough for $\mathrm{NO}_{3}^{-}-\mathrm{N}$ to leach below the root zone.

\section{Nitrogen use efficiency}

The NUE in Juva was $30-52 \%$ and in Mietoinen $49-64 \%$, which are on average more than the NUE of Finnish barley cultivated with mineral fertilisers (34\%, Muurinen et al. 2006) as well as the NUE for global cereal production with conventional fertiliser application (Raun and Johnson 1999). Vinther et al. (2004) found in their studies that microbial communities were more efficient in utilising the $\mathrm{C}$ sources in grass-clover systems than in systems without legumes. This also resulted in a higher NUE in grass-clover systems.

All parameters for the incorporated biomass correlated negatively with the NUE, which means that the higher the biomass and amounts of $\mathrm{N}$ incorporated, the lower the NUE. A higher C:N in the incorporated biomass had a positive impact on the NUE, which means that more $\mathrm{C}$ or less $\mathrm{N}$ in the biomass increases the NUE. These results, as well as the results on cereal $\mathrm{N}$ uptake, indicate that the limiting factor for yields might not have been $\mathrm{N}$, but could involve weed infestation.

\section{Nitrogen leaching risk}

The critical point for $\mathrm{N}$ leaching in crop rotation is the period from autumn to spring, with bare soil before sowing. The effect of the age of the ley on the $\mathrm{N}$ leaching risk was insignificant in our experiments, which agrees with the findings of Hansen et al. (2005) and Eriksen et al. (2004). The mineral N level in soil at a depth of $60-90 \mathrm{~cm}$ was quite low, less than $5 \mathrm{~kg} \mathrm{ha}^{-1}$ in Juva, indicating low $\mathrm{N}$ leaching risk. In Mietoinen, the $\mathrm{N}$ amounts at this depth were 
Vol. 17 (2008): 73-87.

two times higher. Variation in mineral $\mathrm{N}$ content was also high and no statistically significant interactions were found. According to Eriksen (2001), N leaching decreases as a function of time after ley incorporation, but this was not observed in our experiments. In Mietoinen this might be because of the higher clay content of the soils compared with the sandy soils of the study of Eriksen (2001). Low mineral $\mathrm{N}$ concentrations after clover-grass leys, as in Juva, can be explained by a natural feedback mechanism driven by soil mineral $\mathrm{N}$ levels. When soil $\mathrm{N}$ is low, legumes dominate and derive most of their $\mathrm{N}$ through BNF, while grasses dominate under high soil N (Ledgard 2001, Spatz and Benz 2001). This feedback functions as a limit to $\mathrm{N}$ inputs from clover and regulates the potential for $\mathrm{N}$ losses, too. Such feedback may have occurred in our experiments, as the OM content of the soil was higher in trial 2 in both locations and the clover content of leys before cereals was higher in trial 1 than in trial 2.

Winter rye with early autumn ploughing did not prevent $\mathrm{N}$ leaching risk as effectively as spring wheat with late autumn ploughing or spring ploughing, although the difference was about $3 \mathrm{~kg} \mathrm{~N} \mathrm{ha}^{-1}$, which is not significant. In Juva, spring oats after spring ploughing yielded as much as spring oats after autumn ploughing indicating that decomposition and $\mathrm{N}$ release take place quickly enough with spring ploughing for the growth of the subsequent cereal. Känkänen et al. (1998) found similar influences, as well.

\section{Conclusions}

Quite surprisingly, the residual effect of grass-clover leys on yields, N uptake and NUE of two sequenced cereals or $\mathrm{N}$ leaching risk was minimal. The biomass and the $\mathrm{N}$ content of the incorporated biomass influenced the residual effect of red clover based leys, but soil characteristics and cropping history have a greater impact than was thought. In our experiments we did not get strong evidence of an influence of $\mathrm{C}: \mathrm{N}$ of incorporated biomass on residual effect of clover ley. In the systems where the ley yields are removed from the field and no other $\mathrm{N}$ input takes place, $\mathrm{N}$ deficiency is most probably the limiting growth factor, especially, if the legume content of the ley, connected to BNF, is low. The rather high NUE values of $30-80 \%$ support this conclusion, too. On the other hand, the NUE correlated negatively with $\mathrm{N}$ amount in incorporated biomass, which can reflect other factors, such as weed infestation, being growth-limiting factors for cereals. Thus, more research is needed to determine the influence of soil characteristics on $\mathrm{N}$ mineralization and $\mathrm{N}$ availability for plants. An explanation should also be found for the observation that soils under several years of cereal cultivation without external $\mathrm{N}$ input still provide sufficient amounts of $\mathrm{N}$ for crops. This includes more studies on the below-ground biomass, in terms of both quality and quantity. Although it is a challenging task, as representative samples are difficult to take in swards with several plant species and washing the roots is quite labour intensive, it would be worthwhile. To achieve high cereal yields, farmers should pay much attention to the control of weeds by harrowing and with appropriate crop rotations in organic farming.

Acknowledgements. We thank the Agricultural Research Foundation of August Johannes and Aino Tiura for the grant to the corresponding author for writing this article. We are also most grateful to Dr Kaija Hakala and Dr Helena Kahiluoto for their very valuable comments.

\section{References}

Allison, F.E. 1973. Soil organic matter and its role in crop production. Developments in soil science. Vol. 3. Amsterdam. Netherlands: Elsevier. 637 p.

Cassman, K.G.S., Peng, S., Olk, D.C., Ladha, J.K., Reichart, W., Doberman, A. \& Singh, U. 1998. Opportunities for increased nitrogen use efficiency from improved recource management in irrigated rice systems. Field Crops Research 56: 7-38.

Djurhuus, J. \& Olsen, P. 1997. Nitrate leaching after cut grass/clover leys as affected by time of ploughing. Soil Use and Management 13: 61-67.

Eriksen, J. 2001. Nitrate leaching and growth of cereal crops following cultivation of contrasting temporary grasslands. Journal of Agricultural Science, Cambridge 136: 271-281.

Eriksen, J., Pedersen, L. \& Jorgensen, J.R. 2006. Nitrate 
Nykänen, A. et al. Residual effect of clover-rich leys

leaching and bread-making quality of spring wheat following cultivation of different grasslands. Agriculture, Ecosystems and Environment 116: 165-175.

Eriksen, J., Vinther, F.P. \& Soegaard, K. 2004. Nitrate leaching and $\mathrm{N}_{2}$-fixation in grasslands of different composition, age and management. Journal of Agricultural Science, Cambridge 142: 141-151.

Esala, M. 1991. Split application of nitrogen: Effects on the protein in spring wheat and fate of ${ }^{15} \mathrm{~N}$-labelled nitrogen in the soil-plant system. Annales Agriculturae Fenniae 30: 219-309.

FAO 2006. World reference base for soil resources 2006. World soil resources reports 103. Rome: Food and Agriculture Organization of the United Nations. 128 p. Available in Internet: http://www.fao.org/AG/AGL/agll/wrb/doc/ wrb2006final.pdf.

Francis, G.S. 1995. Management practices for minimising nitrate leaching after ploughing temporary leguminous pastures in Cantebury, New Zealand. Journal of Contaminant Hydrology 20: 313-327.

Francis, G.S., Haynes, R.J., Sparling, G.P., Ross, D.J. \& Williams, P.H. 1992. Nitrogen mineralisation, nitrate leaching and crop growth following cultivation of a temporary leguminous pasture in autumn and winter. Fertilizer Research 33: 59-70.

Gomez, K.A. \& Gomez, A.A. 1984. Statistical procedures for agricultural research. New York, NY : John Wiley \& Sons, Chichester, Brisbane, Second edition. xvi, ISBN 0-471-87092-7. $680 \mathrm{p}$.

Granstedt, A. 1992. Case studies on the flow and supply of nitrogen in alternative farming in Sweden. I SkillebyFarm 1981-1987. Biological Agriculture and Horticulture 9: 15-63.

Granstedt, A. \& Baeckström G.L. 1998. Studier av vallens förfruktsvärde i ekologisk odling - resultat från två försöksplatser i mellansverige. (Abstract in English). Ekologiskt lantbruk 25. 93 p.

Hansen, J.P., Eriksen, J. \& Jensen, L.S. 2005. Residual nitrogen effect of a dairy crop rotation as influenced by grass-clover ley management, manure type and age. Soil Use and Management 21: 278-286.

Hansson, A.C. 1987. Roots of arable crops: Production, growth dynamics and nitrogen content. Swedish University of Agricultural Sciences, Uppsala. Department of Ecology. Report 28. 28p.

Haynes, R.J. 1986. The decomposition process: mineralisation, immobilization, humus formation and degradation. In: R.J. Haynes (ed.). Mineral Nitrogen in the Plant-Soilsystem. Orlando, FL: Academic press. p. 52-126.

Honeycutt, C.W., Potaro L.J., Avila, K.L. \& Halteman, W.A. 1993. Residue quality, loading rate and soil temperature relations with hairy vetch (Vicia villosa Roth) residue carbon, nitrogen and phosphorus minralization. Biological Agriculture and Horticulture 9: 181-199.

Høgh-Jensen, H., Loges, R., Jørgensen, F.V., Vinther, F.P., Jensen, E.S. 2004. An empirical model for quantification of symbiotic nitrogen fixation in grass-clover mixtures. Agricultural Systems 82: 181-194.

Høgh-Jensen, H. \& Schoerring, J.K. 1997. Residual nitrogen effect of clover ryegrass swards on yield and $\mathrm{N}$-uptake of a subsequent winter wheat crop as studied by use of
${ }^{15} \mathrm{~N}$ methodology and mathematical modelling. European Journal of Agronomy 6: 235-243.

Jansson, S.L. \& Persson, J. 1982. Mineralization and immobilisation of soil nitrogen. In: Stevenson, F.J. (ed.). Nitrogen in Agricultural soils. Madison, WI: Agronomy Monograph 22. American Society of Agronomy. p. 229-252.

Johnston, A.E., McEwen, J., Lane, P.W., Hewitt, M.V., Poulton, P.R. \& Yeoman, D.P. 1994. Efects of one to six year old ryegrass-clover leys on soil nitrogen and on the subsequent yields and fertiliser nitrogen requirements of the arable sequence winter wheat, potatoes, winter wheat, winter beans (Vicia faba) grown on a sandy loam soil. Journal of Agricultural Science, Cambridge 122: 73-89.

Känkänen, H., Kangas, A., Mela, T., Nikunen, U., Tuuri, H. \& Vuorinen, M. 1998. Timing incorporation of different green manure crops to minimize the risk of nitrogen leaching. Agricultural and Food Science in Finland 7: 553-567.

Känkänen, H., Kangas, A., Mela, T., Nikunen, U., Tuuri, H. \& Vuorinen, M. 1999. The effect of incorporation time of different crops on the residual effect on spring cereals. Agricultural and Food Science in Finland 8: 285-298.

Ledgard, S.F. 2001. Nitrogen cycling in low-input legumebased agriculture, with emphasis on legume/grass pasture. Plant and Soil 228: 43-59.

Mosier, A.R., Syers, J.K. \& Freney, J.R. 2004. Agriculture and the nitrogen cycle: Assessing the impacts of fertilizer use on food production and the environment. SCOPE Report 65. Island Press, Washington, USA. 296 p.

Muurinen, S., Slafer, G.A. \& Peltonen-Sainio, P. 2006. Breeding effects on nitrogen use efficiency of spring cereals under northern conditions. Crop Science 46: 561-568.

Nykänen, A., Granstedt, A., Laine, A. \& Kunttu, S. 2000. Yields and clover contents of leys of different ages in organic farming in Finland. Biological Agriculture and Horticulture 18, 1: 55-66.

Raun, W.R. \& Johnson, G. W. 1999. Improving nitrogen use efficiency for cereal production. Agronomy Journal 91: 357-363.

Spatz, G. \& Benz, J. 2001. Two ecological controls of nitrogen fixation in white clover (Trifolium repens). Grassland Science in Europe 6: 11-13.

Tukey, J.W. 1977. Exploratory data analysis. Reading, Massachusetts: Addison-Wesley Publishing Company. p. 27-55.

Turtola, E., Lemola, R., Esala, M., Kiljala, J. \& Joki-Tokola, E. 2003. Nutrient losses from organic and conventional crop rotations: a case study on fine sand soil. In: Oiva Niemeläinen and Mari Topi-Hulmi (ed.). Proceedings of the NJF's 22nd congress 'Nordic Agriculture in Global Perspective', July 1-4, 2003, Turku, Finland. Jokioinen: MTTAgrifood Research Finland, NJF. p. 40. http://portal. mtt.fi/portal/pls/portal30/docs/FOLDER/AGRONET/YHTEISET_HANKKEET/NJF/NJF2003/25.PDF

Vinther F.P., Hansen, E.M. \& Olesen, J.E. 2004. Effects of plant residues on crop performance, $\mathrm{N}$ mineralisation and microbial activity including field $\mathrm{CO}_{2}$ and $\mathrm{N}_{2} \mathrm{O}$ fluxes in unfertilised crop rotations. Nutrient Cycling in Agroecosystems 2: 189-199

Vuorinen, J. \& Mäkitie, O. 1955. The method of soil testing in use in Finland. Agrogeological Publications 63: 1-44. 
Vol. 17 (2008): 73-87.

\title{
SELOSTUS
}

\section{Puna-apilapitoiset nurmet viljojen typen lähteenä ja vaikutus maan typpipitoisuuteen}

\author{
Arja Nykänen, Arthur Granstedt, Lauri Jauhiainen ja Antti Laine \\ Maa-ja elintarviktalouden tutkimuskeskus ja Biodynamic Research Institute
}

Palkokasveja sisältävien nurmien viljely muodostaa luonnonmukaisen viljelykierron perustan. Palkokasvit sitovat ilmasta typpeä (N) Rhizobium -bakteeriensa avulla, ja tämä typpi lannoittaa seuraavia viljelykasveja. Tässä työssä tutkittiin puna-apilapitoisen nurmen jälkeisten kahden viljan sadon määrää, typenottoa sekä typenkäytön tehokkuutta nurmen esikasviarvon selvittämiseksi. Kahdella koepaikalla, Juva ja Mietoinen, tehtiin vuosina 1994 - 1998 yhteensä neljä kenttäkoetta, joissa oli erilaiset maalajit, viljelyhistoria ja ilmastoolosuhteet. Kokeissa oli syysrukiin, kevätvehnän ja kauran esikasveina 1-, 2- ja 3-vuotiset nurmet sekä viljan monokulttuuri. Nurmen iän sekä sadon määrän, $\mathrm{C}: \mathrm{N}$-suhteen, biologisen typensidonnan määrän ja kokonaistypen määrän vaikutusta seuraaville viljoille tutkittiin nurmen esikasviarvoon vaikuttavina nurmen ominaisuuksina. Lisäksi typen huuhtoutumisriskin selvittämiseksi maasta mitattiin liukoisen typen määriä nurmen muokkauksen jälkeen ja viljojen kasvaessa. Nurmen iällä ei ollut tilastollisesti merkitsevää vaikutusta seuraavien viljojen satoihin. Nurmien esikasviarvo oli viljoille $5-20 \mathrm{~kg} \mathrm{~N}^{-1}$ vuosittain. Viljojen typen käytön tehokkuus nurmen jälkeen oli 30-80 \%. Maahan muokatun nurmibiomassan määrä, kokonaistypen ja biologisesti sidotun typen määrä sekä $\mathrm{C}: \mathrm{N}$-suhde vaikutti viljojen satoon, typen ottoon sekä typen käytön tehokkuuteen. Peltojen viljelyhistoria ja muut ominaisuudet, kuten maalaji ja multavuus on hyvä tietää, kun peltojen viljelytoimenpiteitä suunnitellaan, sillä ne vaikuttavat typen sitoutumiseen ja vapautumiseen maasta kasvien käyttöön. Nurmen kyntö keväällä vähensi typen huuhtoutumisriskiä verrattuna syyskyntöön, mutta vaikutus oli vain 1-3 $\mathrm{kg} \mathrm{ha}^{-1}$, johtuen kaiken kaikkiaan alhaisista liukoisen typen pitoisuuksista. Typen huuhtoutumisriski oli Juvalla alhainen, sillä maan liukoisen typen määrät 30-90 cm syvyydessä olivat pääasiassa $10 \mathrm{~kg} \mathrm{ha}^{-1}$ vuosittain, kun maahan muokattiin vain nurmen juuret, sänki ja kasvijätteet eikä peltoon lisätty karjanlantaa. Mietoisten savimaalla liukoisen typen pitoisuudet olivat jopa $25 \mathrm{~kg} \mathrm{ha}^{-1}$. Jatkotutkimus olisi tarpeen selvittämään, miksi usean vuoden peräkkäisen viljanviljelyn jälkeen saavutettiin vähintään yhtä hyviä viljasatoja kuin nurmen jälkeen ja kuinka kauan tällainen tilanne voi jatkua. 